\title{
Program KPU Kota Padang dalam Meningkatkan Partisipasi Pemilih Pemula Melalui Jambore Demokrasi Pelajar
}

\author{
Yulia Fitria, Suryanef \\ Program Studi Pendidikan Pancasila dan Kewarganegaraan \\ Universitas Negeri Padang \\ E-mail: yuliafitria2015@gmail.com
}

\section{ABSTRAK}

Tujuan penelitian ini adalah untuk mendeskripsikan upaya Komisi Pemilihan Umum Kota Padang dalam meningkatkan partisipasi pemilih pemula melalui program Jambore Demokrasi Pelajar. Jenis penelitian ini adalah kualitatif dengan menggunakan metode deskriptif. Pemilihan informan dilakukan dengan teknik purposive sampling. Hasil penelitian ini menunjukkan bahwa pelaksanaan kegiatan Jambore Demokrasi Pelajar dapat meningkatkan partisipasi pemilih pemula di Kota Padang pada pemilihan Walikota dan Wakil Walikota Padang Tahun 2018 dan Pemilu Serentak Tahun 2019. Adapun faktor penghambat dalam pelaksanaan Jambore Demokrasi Pelajar ini yaitu KPU Kota Padang belum memiliki modul tentang pendidikan pemilih, sehingga kegiatan Jambore Demokrasi Pelajar tersebut banyak diisi dengan kegiatan yang tidak terencana. Selain itu, adanya kesulitan dalam mengendalikan peserta dikarenakan lokasi kegiatan yang sangat luas dan mudah diakses dengan pintu masuk mudah dijangkau oleh banyak orang, serta fasilitas tempat mandi dan listrik di lokasi Jambore kurang memadai untuk digunakan oleh banyaknya peserta Jambore Demokrasi Pelajar tersebut. Sedangkan upaya yang dilakukan oleh KPU Kota Padang dalam mengatasi faktor penghambat tersebut yaitu membuat modul pendidikan pemilih sebagai bekal untuk kegiatan Jambore Demokrasi Pelajar selanjutnya, memperketat pengamanan di lokasi kegiatan dan juga menyediakan fasilitas tempat mandi dan listrik yang cukup untuk peserta Jambore Demokrasi Pelajar tersebut. Dapat disimpulkan bahwa kegiatan Jambore Demokrasi Pelajar dapat dilaksanakan dengan maksimal apabila kegiatan Jambore Demokrasi Pelajar tersebut memiliki modul khusus pendidikan pemilih dan fasilitas yang memadai.

Kata Kunci: Komisi Pemilihan Umum, Pemilih Pemula, Jambore Demokrasi Pelajar

\section{ABSTRACT}

The purpose of this research is to describe the Padang City General Election Commission program in increasing the participation of beginner voters through the activities of the Student Democracy Jamboree. This type of research is qualitative using a descriptive method. The selection of informant is done by purposive sampling technique. The results of this study showed that the implementation of the Student Democracy Jamboree can increase the participation of beginner voters in Padang City in the election of mayor and vice Mayor of Padang year 2018 and simultaneous elections year 2019. As for the inhibitory factor in 
implementing the Student Democracy Jamboree, Padang City General Election Commission does not have a module on voters education, so that the Student Democracy Jamboree activities are filled with activities that are not Planned. In addition, there are difficulties in controlling the participants because the location of activities are very wide and easily accessible with the entrance easily accessible by many people, as well as bathing facilities and electricity in the location of jamboree insufficient to Used by many participants of the Student Democracy Jamboree. Meanwhile, the efforts made by the Padang City General Election Commission to overcome the inhibitory factor is to create a module electorate education as a provision for the activities of the next Student Democracy Jamboree, tighten the security on site Activities and also provide adequate bathing and electrical facilities for participants of the Student Democracy Jamboree. It can be concluded that the activities of the Student Democracy Jamboree can be carried out to the fullest when the Student Democracy Jamboree activities have a special module on voters education and adequate facilities.

Keywords : Komisi Pemilihan Umum, Starter Selector, Student Democracy Jamboree

This work is licensed under the Creative Commons Attribution-ShareAlike 4.0 International License. (C2019 by author.

\section{PENDAHULUAN}

Pemilih pemula selalu menjadi sasaran utama setiap pemilu. Ini karena pemilih pemula merupakan warga negara yang baru pertama kali akan menggunakan hak pilihnya dalam pemilu. Yuningsih dan Warsono (2014: 22) menyatakan bahwa pemilih pemula merupakan pemilih yang baru pertama kali memilih karena usia baru memasuki 17 hingga 21 tahun. Menurut Manik, dkk (2015: 17) pemilih pemula merupakan mereka yang memasuki usia memilih dan untuk pertama kalinya menggunakan hak pilih mereka dalam pemilu/pilkada. Pemilih pemula merupakan pemilih yang potensial dibandingkan kelompok pemilih lainnya. Hal ini karena pemilih pemula merupakan pemilih yang secara kuantitas jumlahnya lebih banyak dari kelompok pemilih lainnya di setiap pelaksanaan pemilu.

Tidak hanya dikategorikan sebagai pemilih yang jumlahnya lebih banyak dari pemilih lainnya, pemilih pemula juga merupakan pemilih yang mudah dipengaruhi oleh pihak lain dalam pelaksanaan pemilu. Hal ini dikarenakan pemilih pemula belum memiliki pengetahuan yang cukup terkait proses pelaksanaan pemilu tersebut. Seperti yang dikemukakan oleh Bakri, dkk (Suryanef dan Al Rafni, 2015: 571) menyatakan bahwa ada beberapa hal yang dapat menggambarkan perilaku pemilih pemula yaitu: (1) pemilih yang masih labil, (2) pemilih yang pengetahuan politiknya masih rendah, (3) pemilih yang cenderung kelompok, (4) pemilih yang melakukan pilihan karena partai atau calon yang diusulkan partai politik tersebut dikenal oleh banyak orang, (5) pemilih yang datang ke TPS hanya sekedar untuk mencoblos saja sebagai tanda ia sudah menggunakan hak pilihnya. Dari paparan diatas dapat dipahami bahwa pemilih pemula cenderung menjadi sasaran para elite politik pada saat diadakannya pemilu karena pemilih 
pemula tersebut pada umumnya belum memiliki pengetahuan yang cukup terkait proses pelaksanaan pemilu itu sendiri.

Oleh karena itu, perlu diadakan pendidikan politik dan pendidikan pemilih agar pemilih pemula dapat menggunakan hak pilihnya dengan tepat tanpa dipengaruhi oleh pihak manapun. Hal ini sudah menjadi tugas pemerintah dimana KPU kerjasama masyarakat agar pendidikan politik tersebut dapat berjalan dengan baik dan dapat diberikan kepada seluruh masyarakat di Indonesia. Seperti yang dikemukakan dalam beberapa hasil penelitian terdahulu yaitu penelitian oleh Setiawan (2015) menyatakan bahwa stategi KPU dalam meningkatkan partisipasi pemilih pemula dalam pilkada Kabupaten Bantul yaitu dengan memaksimalkan kemampuan media elektronik dalam melakukan sosialisasi politik. Penelitian oleh M.Yusuf.A.R (2010) menyatakan peran KPU dalam melakukan pendidikan politik yaitu dengan melakukan sosialisasi tentang pemilu melalui media massa. Serta penelitian oleh Haryono,dkk (2016) menyatakan bahwa strategi KPU dalam meningkatkan partisipasi pemilih yaitu dengan cara melakukan sosialisasi politik tatap muka dan melalui media, baik media cetak, media massa dan media elektronik. Dari paparan di atas dapat kita simpulkan bahwa penelitianpenelitian terdahulu lebih terfokus pada sosialisasi politik dengan menggunakan media massa seperti internet, media sosial, spanduk, pamphlet dan lain sebagainya. Namun tidak semua masyarakat memperhatikan proses sosialisasi politik melalui media massa tersebut, ada yang menganggap tidak penting atau menganggap hal tersebut seperti angin lalu saja sehingga menyebabkan sosialisasi tersebut menjadi tidak efektif.

Berbeda dengan hasil penelitian-penelitian sebelumnya yang hanya terfokus pada sosialisasi politik melalui media massa, KPU di Kota Padang memiliki strategi yang berbeda dalam menarik minat pemilih untuk meningkatkan partisipasi masyarakat dalam pemilu terutama dalam mensukseskan Pilkada Kota Padang 2018 dan pemilu serentak tahun 2019. Strategi unik yang dilakukan oleh KPU Kota Padang yaitu melakukan simulasi pelaksanaan pemilu melalui kegiatan perkemahan yang dikenal dengan Jambore Demokrasi Pelajar. Jambore Demokrasi Pelajar ini adalah suatu kegiatan sosialisasi dan pendidikan pemilih yang dirancang khusus untuk meningkatkan partisipasi pemilih pemula di Kota Padang. Jambore Demokrasi Pelajar ini merupakan kegiatan simulasi dan praktek tentang proses pelaksanaan pemilu yang dilakukan dalam bentuk pemilu sederhana, dimana para peserta mempraktekkan materi terkait pemilu yang mereka dapatkan dari KPU Kota Padang seperti kegiatan pemilu yang sebenarnya.

Permasalahan dalam penelitian ini adalah rendahnya tingkat partisipasi pemilih pemula dalam setiap pelaksanaan pemilihan umum. Hal ini disebabkan karena pemilih pemula belum memiliki pengetahuan yang cukup terkait pelaksanaan pemilu. Sehingga memungkinkan pemilih pemula mudah untuk dipolitisi dan di pengaruhi oleh orang lain bahkan menjadi sasaran para elite 
politik dalam hal politik uang. Oleh karena itu, KPU Kota Padang melaksanakan Jambore Demokrasi Pelajar ini dengan tujuan untuk memberikan pemahaman dan pengetahuan terkait proses pelaksanaan pemilu kepada pemilih pemula, pentingnya memilih dalam pemilu dan juga diharapkan peserta kegiatan Jambore Demokrasi Pelajar tersebut dapat mengajak teman, keluarga, serta masyarakat disekitarnya untuk memilih dalam pemilu.

\section{METODE PENELITIAN}

Jenis penelitian yang digunakan dalam penelitian ini adalah kualitatif deskriptif, karena penelitian ini berusaha mendeskripsikan peristiwa sebagaimana yang terjadi di lapangan. Lokasi penelitian ini di KPU Kota Padang berdasarkan pertimbangan latar belakang, waktu, tempat, dan kegiatan ini belum pernah dilaksanakan sebelumnya di daerah lain. Pemilihan informan dalam penelitian ini menggunakan teknik purposive sampling dimana peneliti menentukan sendiri informan yang dianggap tahu dalam permasalahan yang sedang diteliti. Informan penelitian ini adalah penanggung jawab kegiatan Jambore Demokrasi Pelajar, ketua p, Kwarcab Kota Padang, dan peserta. Sumber data dalam penelitian ini menggunakan data primer dimana data diperoleh dari hasil wawancara kepada informan dan data sekunder diperoleh dari hasil studi dokumentasi di lokasi penelitian. Teknik pengumpulan data dilakukan melalui wawancara dan studi dokumentasi. Dalam menguji keabsahan data dalam penelitian ini, penulis menggunakan teknik triangulasi sumber. Selanjutnya data yang diperoleh akan dianalisis melalui tahap reduksi data, penyajian data, dan penarikan kesimpulan.

\section{HASIL DAN PEMBAHASAN}

Undang-Undang Nomor 7 Tahun 2017 tentang Pemilihan Umum Pasal 1 Ayat (8) menyatakan bahwa "Komisi Pemilihan Umum (KPU) adalah lembaga penyelenggara pemilu yang bersifat nasional, tetap, dan mandiri dalam melaksanakan pemilu". Kemudian UU ini juga menyatakan bahwa KPU memiliki beberapa kedudukan yaitu KPU Pusat yang berkedudukan di ibukota negara RI, KPU Provinsi berkedudukan di ibu kota provinsi, KPU Kabupaten/Kota berkedudukan di pusat pemerintahan kota. KPU merupakan salah satu lembaga pemerintah yang bertugas dalam memberikan sosialisasi politik, pendidikan politik, dan pendidikan pemilih kepada masyarakat. Hal ini bertujuan untuk memberikan pemahaman dan bekal kepada setiap warga negara agar dapat berpartisipasi secara aktif dalam setiap kegiatan perpolitikan di negaranya sendiri.

Salah satu sasaran dari kegiatan sosialisasi dan pendidikan politik serta pendidikan pemilih yaitu pemilih pemula. Hal ini dikarenakan pemilih pemula merupakan salah satu kelompok pemilih yang potensial dari kelompok pemilih lainnya. Tidak hanya dari segi kuantitas yang jumlahnya lebih banyak dari kelompok pemilih lainnya, pemilih pemula ini selalu menjadi perhatian pemerintah, penyelenggara pemilu, serta para elite politik pada setiap diadakannya pemilu. Manik (2015:16) menyatakan bahwa pemilih pemula merupakan pemilih yang tergolong ke dalam kelompok pemilih strategis hal 
ini dikarenakan pemilih pemula merupakan pemilih yang jumlahnya lebih banyak dari pemilih lainnya dan juga pemilih yang berada pada posisi strategis yaitu pemilih yang baru pertama kali akan menggunakan hak pilihnya dalam pemilu. Oleh karena itu, KPU Kota Padang melakukan strategi yang unik dalam memberikan sosialisasi politik, pendidikan politik serta pendidikan pemilih kepada pemilih pemula yaitu dengan melakukan pendidikan pemilih melalui kegiatan perkemahan yang dikenal dengan kegiatan Jambore Demokrasi Pelajar.

Kegiatan Jambore Demokrasi Pelajar ini bertujuan untuk memberikan pendidikan politik kepada pemilih pemula tentang bagaimana mengelola pemilu mulai dari tahap persiapan sampai tahap akhir pemilu itu sendiri, dan menanamkan kepada peserta jambore akan pentingnya ikut ke TPS dan menggunakan haknya untuk memilih. Kegiatan Jambore Demokrasi Pelajar ini juga diharapkan dapat memberikan pengetahuan kepada pemilih pemula tentang bagaimana proses berjalannya demokrasi di Indonesia khususnya pada Pilkada 2018 serta Pemilu serentak tahun 2019 nanti. Setelah mendapatkan pengetahuan dan pengalaman dari kegiatan Jambore Demokrasi Pelajar ini, peserta bisa menjadi duta untuk mengajak rekanrekannya sesama sekolah, keluarga dan masyarakat di lingkungan tempat tinggalnya ke TPS untuk memilih dalam pemilu.

\section{Bentuk Pelaksanaan Kegiatan Jambore Demokrasi Pelajar}

Kegiatan Jambore Demokrasi Pelajar ini dirancang dalam bentuk perkemahan di Lemdadika Padang Besi dari tanggal 6-8 Oktober 2017 dengan pesertanya sebanyak 43 sekolah ditingkat SMA/SMK/MA sekota Padang. Dengan masing-masing sekolah mengutus 8 orang siswa-siswi dan seorang guru Pembina yang jika ditotalkan berjumlah 387 orang. Latar belakang dilaksanakannya kegiatan Jambore ini karena rendahnya tingkat partisipasi pemilih terutama pemilih pemula pada saat Pemilu. Selain itu, kegiatan Jambore Demokrasi Pelajar ini dilaksanakan karena adanya keterbatasan KPU Kota Padang dalam menjangkau pemilih untuk memberikan sosialisasi politik, pendidikan politik dan pendidikan pemilih. Selain itu, kegiatan ini dilakukan sebagai bentuk upaya baru dan sebagai bentuk evaluasi dari kegiatan sosialisasi politik dan pendidikan pemilih yang sudah pernah dilakukan KPU Kota Padang sebelumnya dengan tujuan untuk meningkatkan partisipasi pemilih dalam setiap pelaksanaan Pemilu.

Kegiatan Jambore ini bertujuan untuk memberikan pendidikan pemilih secara aplikatif kepada pemilih pemula terkait proses pelaksanaan pemilu, mewujudkan pemilih yang terlibat secara aktif dalam setiap pelaksanaan pemilu dan mengajak teman, keluarga maupun masyarakat sekitar untuk mengikuti pemilu. Selanjutnya kegiatan ini dapat meningkatkan partisipasi pemilih dalam pemilu sekaligus untuk mensukseskan pelaksanaan Pilwako Tahun 2018 dan Pemilu Serentak Tahun 2019 di Kota Padang. KPU Kota Padang juga dapat menciptakan agenagen pendidikan pemilih yang dapat membantu dalam memberikan pendidikan pemilih kepada 
masyarakat. Menurut Manik (2015: 6), pendidikan pemilih ini bertujuan untuk meningkatkan partisipasi pemilih dalam pemilu, menambah pengetahuan masyarakat terikait pemilu dan juga meningkatkan kesadaran politik dalam diri suatu individu.

\section{Pelaksanaan kegiatan Jambore Demokrasi Pelajar ini terbagi dalam tiga tahap kegiatan yaitu:}

\section{a) Tahap Perencanaan}

Pada tahap perencanaan ini KPU Kota Padang melakukan berbagai persiapan tentang konsep kegiatan, sarana dan prasarana serta kerjasama dengan berbagai pihak yang dapat mendukung kelancaran kegiatan Jambore tersebut. Pada tahap persiapan ini KPU Kota Padang beserta seluruh pihak yang terlibat melakukan beberapa kali rapat, baik itu rapat gabungan seluruh panitia pelaksana maupun rapat internal untuk menentukan konsep kegiatan, pihak yang akan terlibat, tempat kegiatan dan hal-hal yang dibutuhkan dalam pelaksanaan kegiatan Jambore. Atmosudirjo dalam Taufiqurokhman (2008) menyatakan bahwa perencanaan merupakan upaya memperhitungkan dan menentukan sesuatu yang akan dilakukan untuk mencapai tujuan tertentu, orang yang akan terlibat, kapan dan dimana, dan bagaimana melakukannya. Dalam hal ini ada enam kali rapat yang dilakukan oleh KPU Kota Padang dengan beberapa pihak yang terlibat dalam kegiatan Jambore. Pihak yang terlibat dalam kegiatan Jambore Demokrasi Pelajar ini yaitu KPU Kota Padang sendiri, Kwarcab Pramuka Kota Padang, dan PMI Cabang Padang.
Dari segi konsep kegiatan, KPU Kota Padang menggunakan konsep perkemahan atau yang biasa dilakukan oleh orang-orang yang terlibat dalam kegiatan kepramukaan yaitu kegiatan Jambore. Seperti yang dikemukakan oleh Sulaeman dalam Rinaldi (2015) mengatakan bahwa berkemah merupakan suatu kegiatan yang mengandung unsur pendidikan dan dilakukan dengan cara bermalam serta melakukan kegiatan secara berkelompok di alam terbuka. Artinya kegiatan Jambore ini merupakan kegiatan yang dilakukan di alam terbuka. Dengan mengadopsi kegiatan perkemahan atau Jambore tersebut, KPU Kota Padang bekerja sama dengan Kwarcab Pramuka Kota Padang untuk mendesain skenario kegiatan seperti kegiatan perkemahan pada umumnya. Selain itu dari segi teknis di lapangan, KPU Kota Padang bekerja sama dengan Kwarcab Pramuka Kota Padang dalam mengarahkan peserta dalam setiap kegiatan. Selain itu, KPU Kota Padang juga melakukan kerjasama dengan PMI Cabang Padang untuk membantu peserta kegiatan apabila ada yang sakit.

b) Tahap Pelaksanaan Kegiatan

Pada tahap pelaksanaan kegiatan hari pertama tanggal 6 Oktober 2017, peserta datang ke tempat kegiatan, mendirikan tenda sebagaimana kegiatan perkemahan pada umumnya dan mengikuti seluruh rangkaian kegiatan yang telah ditetapkan oleh panitia pelaksana kegiatan. Menurut Agustrian, dkk (2017) pelaksanaan merupakan upaya yang dilakukan untuk menjalankan apa yang telah direncanakan sebelumnya melalui arahan dan motivasi agar kegiatan 
Volume 1 No. 42018

dapat berjalan dengan optimal dan sesuai dengan tujuan yang ditetapkan. Kemudian pada malam harinya peserta Jambore diberikan pemahaman materi terkait proses pelaksanaan pemilihan umum, lembaga-lembaga penyelenggara pemilu, serta pentingnya memilih dalam pemilu. Materi tersebut langsung disampaikan oleh Komisioner KPU Sumatera Barat. Dalam kegiatan tersebut, peserta diajak untuk berdiskusi dan langsung mempraktekkan pengetahuan yang mereka dapatkan pada proses pelaksanaan pemilu yang sebenarnya. Peserta diminta untuk mendaftarkan dirinya untuk terlibat sebagai penyelenggara pemilu seperti anggota KPU, KPPS, PPS dan lain sebagainya kepada panitia kegiatan. Dalam hal ini peserta Jambore Demokrasi Pelajar dikondisikan pada proses pelaksanaan pemilu sederhana yang disebut dengan pemilihan Walikota dan Wakil Walikota Jambore.

Pada hari kedua tanggal 7 Oktober 2017 merupakan hari dimana peserta Jambore Demokrasi Pelajar mempraktekkan materi terkait proses pelaksanaan pemilu yang mereka dapatkan sebelumnya seperti pelaksanaan pemilu yang sebenarnya yaitu pemilihan Walikota dan Wakil Walikota Jambore. Kegiatan yang dilakukan sama seperti proses pelaksanaan pemilu pada umumnya seperti calon Walikota dan Wakil Walikota mendaftarkan diri ke KPU Jambore, melakukan kampanye, debat, melakukan pemilihan, perhitungan suara dan penetapan calon yang terpilih sebagai Walikota dan Wakil Walikota Jambore. Hal ini sejalan dengan pendapat yang dikemukakan oleh Manik, dkk dalam bukunya yang berjudul Pedoman Rumah Pintar Pemilu, yang menyatakan bahwa ada beberapa tahapan dalam pemilu yaitu pembentukan badan adhoc, pemutakhiran data pemilih, pendaftaran calon peserta pemilu, kampanye, pemungutan dan penghitungan suara, dan penetapan calon terpilih. Pelaksanaan pemilu jambore tersebut dirancang sedemikian rupa menyerupai pelaksanaan pemilu pada umumnya dengan tujuan agar peserta Jambore Demokrasi Pelajar dapat merasakan dan memahami setiap tahap-tahap yang harus dilakukan dalam setiap pelaksanaan pemilu.

Pada saat peserta akan mendaftarkan dirinya pada KPU Jambore, calon Walikota dan Wakil Walikota Jambore tersebut diarak secara bersama-sama oleh tim pendukungnya dengan menggunakan kreasinya masing-masing, ada yang memakai baju adat dan aja juga yang memakai seragam batik. Kegiatan tersebut dilakukan dengan tujuan untuk memperkenalkan kepada seluruh masyarakat Kampung Jambore bahwa mereka adalah caloncalon yang akan terlibat dalam pelaksanaan pemilihan Walikota dan Wakil Walikota Jambore pada saat itu. Hal ini sejalan dengan Peraturan KPU Republik Indonesia Nomor 23 tahun 2018 Pasal 1 Ayat 21 tentang Kampanye Pemilu yang menyatakan bahwa kampanye adalah kegiatan peserta pemilu atau pihak lain yang ditunjuk oleh peserta pemilu untuk meyainkan pemilih dengan menawarkan visi, misi, program, dan/atau citra diri peserta pemilu. Setelah melakukan pendaftaran, pasangan yang telah mendaftar diseleksi dulu oleh KPU Jambore, 
apakah sudah memenuhi persyaratan atau belum. Selanjutnya, pasangan calon yang terpilih melakukan kampanye dan debat terkait visi dan misi apabila pasangan calon terpilih menjadi Walikota dan Wakil Walikota Jambore.

Pada hari selanjutnya tanggal 8 Oktober 2017, peserta melakukan pemungutan suara untuk memilih Walikota dan Wakil Walikota Jambore. Kegiatan tersebut dirancang seperti pelaksanaan pemilihan pada umumnya yaitu KPU Kota Padang memfasilitasi kegiatan tersebut dengan peralatan pemilu yang dimiliki oleh KPU Kota Padang seperti adanya surat suara, kotak suara, bilik suara dan lain sebagainya. Setelah pelaksanaan pemilihan selesai, hasil suara tersebut dihitung oleh anggota KPPS Jambore dan setelah mendapatkan siapa yang menjadi pemenang dalam pemilihan Walikota dan Wakil Walikota tersebut, KPU Jambore mengumumkan Walikota dan Wakil Walikota Jambore yang terpilih dan kemudian dilantik oleh pihak KPU Kota Padang. Pasangan calon Walikota dan Wakil Walikota Jambore yang terpilih ini dikenal sebagai Duta Jambore Demokrasi Pelajar.

c) Tahap Evaluasi Kegiatan

Evaluasi merupakan penilaian terhadap suatu kegiatan yang telah dilakukan. Arifin dalam Asrul, dkk (2014) mengatakan bahwa evaluasi merupakan suatu proses yang dilakukan untuk mengetahui dan menentukan kualitas dari kegiatan yang dilakukan berdasarkan pertimbangan dan kriteria tertentu. Evaluasi terkait pelaksanaan kegiatan Jambore Demokrasi Pelajar yaitu peserta merasa senang dan antusias dalam mengikuti kegiatan Jambore tersebut karena kegiatan tersebut memiliki konsep belajar sambil bermain dan dapat melibatkan seluruh peserta dalam setiap kegiatan. Peserta paham dengan materi yang diberikan oleh KPU Kota Padang dan dengan adanya kegiatan Jambore Demokrasi Pelajar ini mendorong peserta untuk terlibat dalam pelaksanaan pemilu terutama pada pemilihan Walikota dan Wakil Walikota Padang 2018. Kendala dalam kegiatan jambore serta upaya yang dilakukan untuk mengatasi kendala dapat dijelaskan berdasarkan tabel berikut ini:

Tabel.1

Kendala dan Upaya

\begin{tabular}{|c|c|c|}
\hline No & $\begin{array}{c}\text { Kendala dalam } \\
\text { pelaksanaan } \\
\text { kegiatan Jambore } \\
\text { Demokrasi Pelajar }\end{array}$ & $\begin{array}{c}\text { Upaya KPU Kota } \\
\text { Padang untuk } \\
\text { mengatasi kendala } \\
\text { tersebut }\end{array}$ \\
\hline 1. & 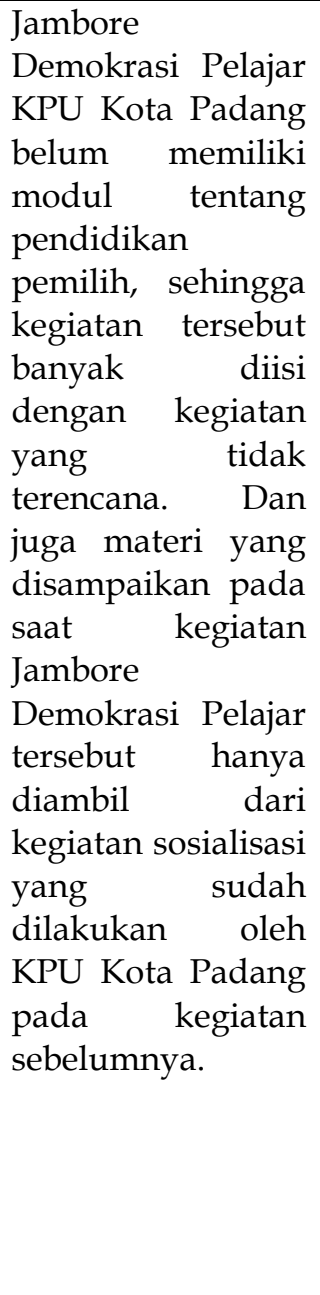 & 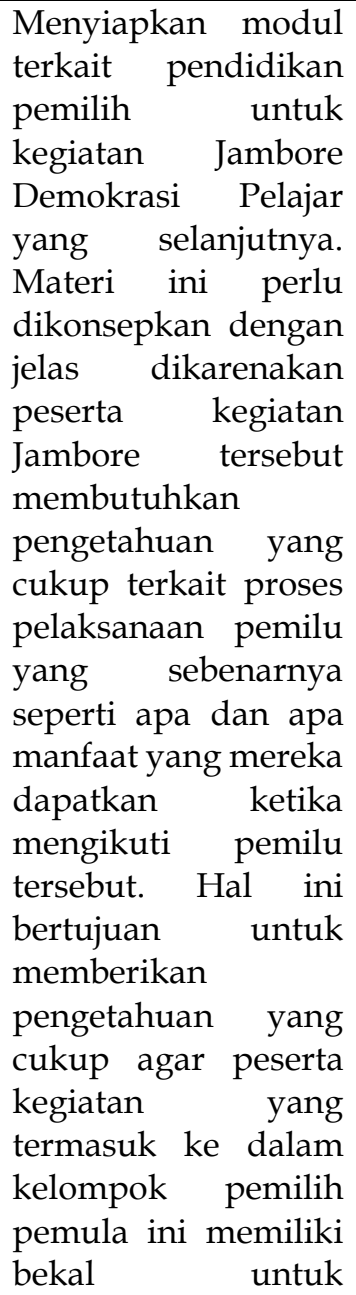 \\
\hline
\end{tabular}




\begin{tabular}{|c|c|c|}
\hline & & 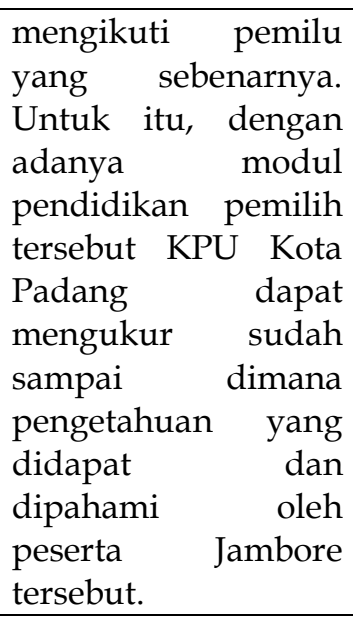 \\
\hline 2. & 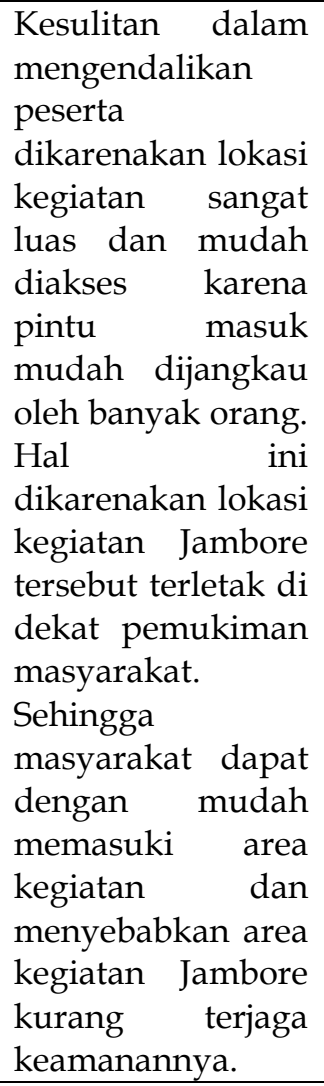 & \begin{tabular}{lr}
\multicolumn{2}{l}{ Meningkatkan } \\
keamanan di lokasi \\
kegiatan & karena \\
lokasi & kegiatan \\
merupakan tempat & yang mudah diakses \\
oleh banyak orang. \\
Dan juga lokasi \\
kegiatan berada \\
dekat dengan \\
pemukiman \\
masyarakat, \\
sehingga \\
memungkinkan \\
masyarakat dengan \\
mudah untuk keluar \\
masuk di lokasi \\
kegiatan Jambore \\
tersebut.
\end{tabular} \\
\hline 3. & 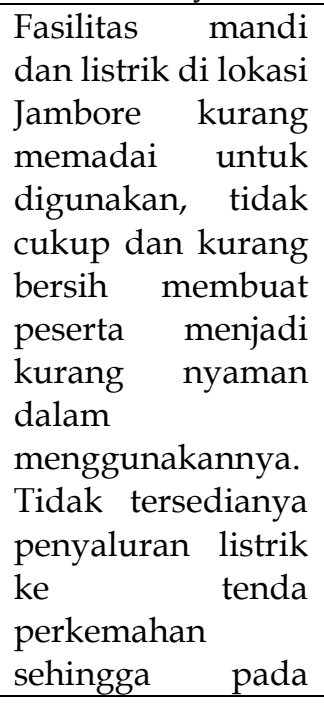 & $\begin{array}{l}\text { Menyediakan } \\
\text { fasilitas kamar mandi } \\
\text { dan aliran listrik } \\
\text { yang cukup atau } \\
\text { menyediakan } \\
\text { alternatif lain untuk } \\
\text { peserta Jambore } \\
\text { mengingat peserta } \\
\text { yang terlibat cukup } \\
\text { banyak Hal ini } \\
\text { dikarenakan fasilitas } \\
\text { kamar mandi dan } \\
\text { listrik tersebut juga } \\
\text { menjadi faktor } \\
\text { penunjang } \\
\text { kelancaran peserta }\end{array}$ \\
\hline
\end{tabular}

Volume 1 No. 42018

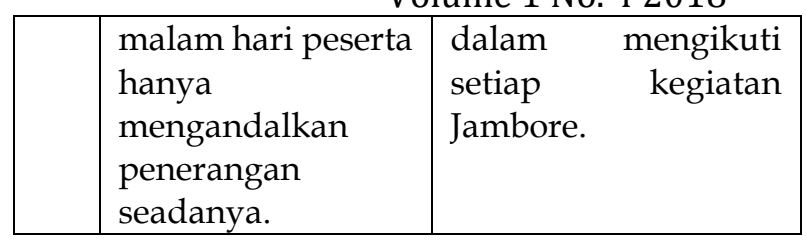

\section{KESIMPULAN}

Berdasarkan uraian hasil
penelitian diatas, maka dapat disimpulkan bahwa Jambore Demokrasi Pelajar ini merupakan suatu kegiatan pendidikan politik dan pendidikan pemilih yang dilakukan dalam bentuk simulasi dan praktek terkait proses pelaksanaan pemilu sehingga dapat memberikan kemudahan kepada peserta atau pemilih pemula untuk memahami materi terkait proses pelaksanaan pemilu tersebut. Pelaksanaan kegiatan Jambore Demokrasi Pelajar ini bertujuan untuk menambah wawasan pemilih pemula terkait proses pelaksanaan pemilu, paham akan pentingnya memilih dalam pemilu, dan meningkatkan partisipasi pemilih pemula pada Pemilihan Walikota dan Wakil Walikota Padang Tahun 2018 dan Pemilu Serentak tahun 2019 dan juga menjadikan pemilih pemula yang terlibat dalam kegiatan Jambore Demokrasi pelajar tersebut menjadi duta di lingkungannya untuk menggunakan hak pilihnya dalam pemilu.

Dalam pelaksanaan kegiatan Jambore Demokrasi Pelajar ini ada beberapa tahap yang dilakukan oleh KPU Kota Padang yaitu tahap persiapan, pelaksanaan, dan tahap evaluasi kegiatan Jambore Demokrasi Pelajar tersebut. Kendala yang ditemui dalam pelaksanaan kegiatan Jambore tersebut yaitu KPU Kota Padang belum memiliki modul terkait pendidikan pemilih pada saat itu, 
lokasi kegiatan yang luas sehingga keamanan lokasi kegiatan kurang maksimal serta fasilitas untuk peserta kegiatan yang kurang memadai. Upaya yang dilakukan oleh KPU Kota Padang untuk mengatasi kendala tersebut yaitu dengan membuat modul untuk kegiatan Jambore yang selanjutnya, memperketat keamanan lokasi kegiatan, dan menyediakan fasilitas yang cukup untuk digunakan oleh peserta kegiatan Jambore Demokrasi Pelajar mengingat peserta yang terlibat cukup banyak.

\section{DAFTAR PUSTAKA}

Asrul, dkk. 2014. Evaluasi Pembelajaran. Bandung: Citapustaka Media

Haryono, Dwi.dkk. 2016. Strategi KPU dalam Meningkatkan Partisipasi Pemilih Pada Pemilihan Walikota dan Wakil Walikota Samarinda Tahun 2015. Ejournal Administrative Reform. 4 (2): 204-215 ISSN: 2338-7637

Manik, Husni Kamil. 2015. Buku Pedoman Pendidikan Pemilih. Jakarta: Komisi Pemilihan Umum Repubik Indonesia

Lisa Agustrian, Nyimas. 2017. Manajemen Program Life Skill di Rumah Singgah Al-Hafidz Kota Bengkulu. Jurnal Pengembangan Masyarakat Vol. 1 No. 1

Rinaldi, Ogi. 2015. Kawasan Bumi Perkemahan di Kota Semarang. Jurnal Online Mahasiswa Arsitektur Universitas Tanjungpura Vol. 3 No. 2

Setiawan, Novendi. 2016. Strategi KPU Kabupaten Bantul Untuk Meningkatkan Partisipasi Pemilih Pemula dalam
Pemilihan Kepala Daerah Kabupaten bantul Tahun 2015 Suryanef, Al Rafni. 2015. Pendidikan Pemilih (Voter's Education) bagi Pemilih Pemula serta Urgensinya dalam Pembangunan Demokrasi. Prosiding 2015 Sosial, Ekonomi, dan Humaniora. ISSN 20893590 | EISSN 2303-2472

Taufiqurokhman. 2008. Konsep dan Kajian Ilmu Perencanaan. Jakarta Pusat: Fakultas Ilmu Sosial dan Ilmu Politik Universitas Prof. Dr. Moestopo Beragama

Yulianingsih, Neny Agustin Irma, Warsono. 2014. Partisipasi Politik Remaja (Pemilih Pemula) pada Pemilukada Mojokerto Tahun 2010 di Desa Sumber Tanggul Kecematan Mojosari Kabupaten Mojokerto. Kajian Moral dan Kewarganegaraan Nomor 2 Vol. 1

Yusuf, M. 2010. Peran Komisi Pemilihan Umum (KPU) dalam Pendidikan Politik. Ganec Swara. Vol. 4 No. 1

Peraturan Komisi Pemilihan Umum Republik Indonesia Nomor 23 tahun 2018 Tentang Kampanye Pemilihan Umum

Undang-Undang Nomor 7 Tahun 2017 Tentang Pemilihan Umum. 